\title{
MÚSICA, MAGIA, Y MEDICINA: UNA APROXIMACIÓN ECO-CRÍTICA A LA POESÍA AFRO-CARIBEÑA
}

\section{MUSIC, MAGIC, AND MEDICINE: AN ECO- CRITICAL APPROACH TO AFRO-CARIBBEAN POETRY}

\author{
Beatriz Rivera-Barnes \\ Penn State University
}

\section{RESUMEN}

Este artículo es una aproximación eco-crítica a la poesía Afro-Caribeña de Aimé Césaire, de Nicolás Guillén, y de Luis Palés Matos.

Palabras clave: eco-crítica, poesía Afro-Caribeña, Aimé Césaire, Nicolás Guillén, Luis Palés Matos.

\section{ABSTRACT}

This article is an eco-critical approach to the Afro-Carribean poetry of Aimé Césaire, Nicolás Guillén, and Luis Palés Matos.

Keywords: Eco-criticism, Afro-Carribean poetry, Aimé Césaire, Nicolás Guillén, Luis Palés Matos. 
Music, magic, and medicine, in that order, but in a circular flow instead of a linear or dialectic progression, with music making magic, magic eventually developing into religion but remaining forever tied to medicine or the pharmakon that is either drug, medicine, or poison, therefore fraught with contradiction, the magic of life or death and of duality itself, and medicine turning to music, as in Nicolás Guillén's "Sensemayá," a poem/song for recital to the drum, where the snake twined around a pole is suggestive of the Aesculapian staff, the symbol of the medical profession. Thus, the alliterative trinity-music, magic, and medicine-becomes itself a mystery, three in one, inseparable. By way of the negritude poetry of the Cuban Nicolás Guillén, the Puerto Rican Luis Palés Matos, and the Martíniquan Aimé Césaire, this study will serve as an approach to that trilogy.

It was Aimé Césaire who first used the word negritude in his journal L'Étudiant Noir (The Black Student) in 1934 in an effort to challenge the Antilleans who were so ashamed of being black that they were constantly searching for any kind of paraphrase to designate a black person (LópezBaralt 11). It was a term that Jean-Paul Sartre considered to be "assez laid" (ugly enough) but nonetheless a definable and describable concept subsuming other more elementary concepts corresponding to the immediate fundamental ideas of black consciousness (xviii). Thus, the words nègre (negro, black) and negritude to denote a new spirit of rejection of cultural assimilation and the pursuit of black cultural expression (Ellis 202), as well as to defy the feelings of shame and indignity that can easily be traced all the way back to the $16^{\text {th }}$ century. In spite of this quasi inherited sense of humiliation or what could be labeled a Caliban complex, enslaved Africans and free blacks began to have an impact on European music, poetry, religion, and medicine very early on in the history of slavery in the Caribbean, impact that eventually paved the way for cultural marroonage. In Music in Cuba, the novelist and musicologist Alejo Carpentier mentioned a black sheriff in Havana distinguished for his learned ways, as well as the black man Estevancio known for his miraculous cures who was taken to Florida 
by Pánfilo de Narváez in the late 1520s (79-81). Manifestly, "miraculous cures" suggest both African magic and medicine.

Carpentier also cited a paragraph from Memoria sobre la vagrancia en la Isla de Cuba, where José Antonio Saco wrote in 1832 that, "The arts are in the hands of people of color" (153). The reason that Saco gave for this particular situation was "the habit of despising the work done by blacks," rationalization that Carpentier did not consider sufficient to explain the factors that came into play against music as a profession, such as the prejudices of a colonial society and also the instability and poverty that came with the musician's choice of life path. It could very well be that blacks became musicians because there was no racial discrimination in music, because no one else was interested in this line of unrewarding work, and also for lack of anything else to do, since blacks at the time were barred from the law, the military, the church, public administration, and even medicine although both enslaved and liberated blacks were very often employed in hospitals as nurses and midwives, as well as called upon to practice veterinary medicine, and consulted for information relative to the use of African herbal remedies.

The result is that blacks became either a powerful influence or a vital source of productivity in the musical, magical (religious), and medical fields very early on in the history of the Caribbean. From 1800 to 1840, blacks were the majority of the professional musicians (Music in Cuba 161). And although history recorded few of their names, the historian Karol Weaver underlines the importance in numbers of the enslaved healers such as hospital workers, nurses, midwives, herbalists, veterinary practitioners, and kaperlatas when it came to medicine and society in $18^{\text {th }}$ century Saint Domingue, an influence that would certainly spread to other Caribbean islands (1). Furthermore, at no time did the African medical, cultural, and musical presence cease to be significant, this in spite of the effort on the part of blacks to imitate European music, European meter, European medical conduct, and to mimic Catholicism. If there was imitation, it morphed into a new style: a mestizo music, poetry, folk medicine, and religion that would eventually become Afro-Caribbean.

Poetic language itself would undergo somewhat similar transformations and mutations. The fact that blacks were not allowed to read and to write paved the way for an oral tradition that would eventually re-enact or re-create folkloric traditions into poetry, and lead to a new and unique racial and societal language with modes of expression that would deeply impact the Spanish, the French, and the English spoken throughout the Caribbean, as well as a racial and socio-cultural consciousness that still continues to influence music, dance, and literature. Martha Cobb believes that these inter- 
dictions were not totally negative to a black literary tradition because as a consequence the slaves continued to rely on oral traditions from Africa and were forced to depend on the ear even as they acquired a new language (either French, Spanish, or English) to which they gave their own cadences, embellishments, and style (9).

Manifestly, the sounds and cadences of Caribbean music and poetry would be totally other without the African element. And the African influence is such that its cultural continuities and patterns continue to thrive and evolve, with common elements and bonds: from Haiti, to the Dominican Republic, to Puerto Rico, to Havana, particularly in the suffering that ranges in expression from the poignant, to the polemic, to the humorous (Cobb 6). The critic and political activist Jean-Claude Bajeux, avers that Antillean awareness is rooted in the fusion of the African and European races lle métissage), and also that whether one chooses to accept this or ignore this, negritude is Antillean and the Antilles are black (8). So as history had it, Caribbean music or poetry is African in nature, regardless of the color or the hue of the composer's or the poet's skin. In fact, white poets such as the Puerto Rican Luis Palés Matos who were often chastised for being white, and his other white but not quite lily white Cuban counterparts Ramón Guirao and José Tallet were at the beginnings of the negritude movement in the 1920s. Interestingly, Guillén was uncomfortable with the influence that Palés Matos had had on light-skinned Cubans. For the latter had "[...] gone into an almost frenzied state of creativity, producing exotic, erotic verses in which the black female persona of generously proportioned hips and nalgas (posterior) literally held sway, exuding earthy, sultry sensuality" (Smart 33). These ambivalent approaches to Palés Matos still hold to this day, never taking into consideration that Bajeux indicated almost thirty years ago that there had been little or no debate as to whether or not Palés Matos was at the heart of Antillean nationalism, or if this stance had been explicitly exploited, as it had with Guillén (12). More recently, the critic Mercedes López-Baralt argued that the complexity of Azaleas (1915) and of Tuntún (1937 and 1950) has often been overlooked (13), and it continues to be so, for Palés Matos is still surrounded by either Calibans or Prosperos.

Inevitable political considerations aside, the connection between poetry and music should be manifest, notwithstanding the fact that the roots of these words set them apart and put them in two different categories: action and technique or knowledge. The Greek word poetica is derived from the verb poiein, to make, whereas the mousika tekhne where the arts governed by the muses that were subsequently split into three kinds in medieval times: universalis (universal), mundana (wordly), and instrumentalis (instrumental). It is not only the musica instrumentalis that concerns us here, for the musica 
mundana had to do with the human body. In spite of these differentiating details, the words music and poetry are oftentimes interchangeable. Medieval poetry anthologies in France, Spain, and Italy were known either as chansonniers, cancioneros, or canzionere (song books), and epic poetry in Spain was oftentimes considered to be "historia cantada," or history put to song, resulting in epic poems such as: El cantar del mio Cid (The Song of My Cid), la Chanson de Roland (The Song of Roland), Petrarch's Canzionere (Song Book). But this connection was not severed after the Middle Ages and the Renaissance, on the contrary it has remained unbroken, there has forever been an effort to use words to make music. Even novels such as Carpentier's Concerto Baroque (Baroque Concert) demonstrates a will to make words adapt to the rules of harmony and to produce a work of prose in doing so. And the list of poetry collections that are called cantos or songs goes on and on: Ezra Pound's Cantos, T.S. Eliot's The Love Song of J. Alfred Prufrock, Pablo Neruda's Canto General (General Song), Guillén's Motivos de Son (Son Motifs), and Cantos Para Soldados y Sones Para Turistas (Songs for Soldiers and Sons for Tourists), and Ruben Darío's Cantos de vida y de esperanza (Songs of Life and Hope), just to name a few. Aimé Césaire even has a poem for whistling on the road: "inventaire des cayes" (inventory of reefs). Again, these are poems that are referred to as songs, and songs are by nature musical. Furthermore, the rhythm and cadence required of poetry forever ties poetry to music. When it comes to the son and the effort to transform the son into poetry, Claude Couffon writes that the son loses its metric rigor in order to become a free play of rhythms representative of the Cuban soul, but that it nonetheless retains its overall structure with the call-response, the first moment called the largo, that sets the stage or the theme, and the second moment, a bit more tense, called the montuno, that provides the rhythmic value and also stresses the importance of the largo (40).

The approximation of music and poetry can equally be found in Octavio Paz's poetics. When Paz delves into a definition of poetry in El Arco y la lira (The Arc and the Lyre) every formula, metaphor, and attempt at a definition can be applied to music. At times poetry is even defined as music and described in musical, temporal, and tonal terms, the poem becomes a seashell where the music of the world is resonating and meters and rimes become echoes of universal harmony (13). The dimension of time is an integral part of both music and poetry because both can be defined as time itself. Paz refers to poetry as temporality, pure time and at the same time the origin of time, the incarnation of the instant where succession becomes pure present (lbid 25). Music could be defined much the same way, in terms of perpetual movement, a world of call and response, with worlds flowing from rhythm 
itself, with rhythm ceasing to be simply measurement and becoming a vision of the world. "La repetición rítmica es invocación y convocación del tiempo original" (lbid 63). (Rhythmic repetition is an invocation and convocation of original time.)

Guillén defines poetry as a variety of sensations, beginning with a familiarity with the natural world that is reminiscent of José Martí"s "Versos Sencillos" (Simple Verses) where the poetic I first knows the strange names of plants and flowers, and also mortal betrayal and sublime pain: "Yo sé los nombres sencillos/de las hierbas y las flores/Y de mortals engaños/Y de sublimes dolores" (58). (I know the simple names of the herbs and the flowers/and of mortal betrayals/and of sublime pain). Similarly, in an essay titled "Poetry and Knowledge," Aimé Césaire writes that "Poetic knowledge is born in the great silence of scientific knowledge" (xlii), but what differentiates poetic knowledge from scientific knowledge is that, "Scientific truth has as its sign coherence and efficacy. Poetic truth has as its sign beauty" (Ibid Iv). However, in spite of these efforts at coherence and efficacy, "scientific knowledge enumerates, measure, classifies, and kills" (Ibid xlii). This is perhaps why Césaire is not necessarily contradicting himself when his conozco, his I know, his je sais becomes: "je sais la merde (et sa quadrature)/ mais merde" (lbid 96). (I know shit and its quadrature/but shit).

For Palés Matos, in turn, poetry was the only way to encounter reality, and the writing of poetry was the privileged place of the junction between dream and reality. Although that holds true for all poetry, Bajeux believed that it was particularly true for Palés Matos precisely because the exploration conducted at the level or reverie and the patient search for a resonant architecture capable of revealing the object of internal vision, in other words capable of approaching reality, or of knowing (112).

In "Arte Poética" (Poetics) published in 1953, Guillén expresses this knowledge, its dichotomies, and the dilemma of depicting horror when, precisely, poetic truth has as its sign beauty: "Conozco la azul laguna/y el cielo doblado en ella" (Summa 159) (I know of the blue lagoon/and of the sky folded into it.) The conozco (I know) in the first person singular suggests that poetry springs from knowledge, in other words that the poetic voice surges in medias res. In furn, the initial familiarity with the natural world prompts the poetic voice to action and intervention, reaching into this natural world, picking a live flower, in other words killing it, but also kissing it, and at the same time learning from the sounds of the natural world: "Un pájaro principal/me enseñó el multiple trino" (lbid ). (A principal bird/ showed me the multiple sounds). But suddenly this seemingly edenic scene is interrupted. Violence takes over: there is dislocation, and immediately reference to lead, iron, death, and incarceration. The sugar cane becomes 
a hungry mouth full of teeth. And there is also regret, because the star in the firmament knows not of hunger and cold. There is reference to the slaves who worked in the sugar cane field, and to their lashings, and this is something that needs to be said, with a guitar, as if music were the only way to express this type of suffering. If it is to be put into words, then the words need to be lyrical. Poetry becomes a way of approaching the world and of saying what cannot be said, for whatever reason: be it political, taboo, shameful, painful, or simply too ugly or too mundane.

In her introduction to the $50^{\text {th }}$ anniversary edition of Motivos de Son, Mirta Aguirre points out that when Guillén inserted the son into literature, he was accused of only being interested in the lowliest social classes and even of intentionally belittling his own race. While dancing to the son was acceptable, to see it put to words was entirely a different matter. "Con música, el son podía pasar; directo y desnudo, llamando en palabras a las cosas por su nombre, era como la glorificación del basurero nacional" (9). (With music the son was passable; blatant and unadorned, calling things by their names, it was like the glorification of the national dumpsite.)

The music and the rhythm that render tolerable and perhaps even "whiten" what Aguirre refers to as the dirty linen taken out to be washed on the public square, in turn, can be considered a magical approach to the universe with an immediate objective: to enchant and to imprison certain forces while exorcising others (Paz 58). Thus the ties that bind music, poetry, and magic intensify, for not only do music, magic, and poetry require participation, but the magical powers of words and of music cannot be denied. "La operación poética no es diversa del conjuro, el hechizo y otros procedimientos de la magia. Y la actitud del poeta es muy semejante a la del mago (Paz 53). (The act of poetry is not very different from that of conjuration, or spellbinding or other works of magic. And the attitude of the poet is very similar to the magician's.) Césaire's poem "mot-macumba" is an excellent example of these ties that bind poetry, magic, and in this case religion: "le mot est père des saints/le mot est mère des saints/avec le mot couresse on peut traverser un fleuve peuple de caïmans" (134). (the word if the father of saints/the words if is the mother of saints/with the word course one can cross a river full of caimans). So not only is the word the father and the mother of saints, but with a single word such as couresse (a popular term for a Martíniquan water snake) one can cross a river swarming with crocodiles. For Césaire, there also exist iguana words (mots iguanes), dolphin words (mot dauphin), Shango words (mots Shango), thunderbird words (le mot oiseau-tonnerre), and dragon of the lake words (le mot dragon-du-lac) (lbid 104). It is the rancor of these words that guide us, but after an enumeration of words, the first person plural of us, becomes a first person singular, 
because the words sniff at me, and come to me, and at the end what is left is no longer the rancor of words, but the atrocious resentment of saliva swallowed again and again by the surf: "et l'atroce rancune de salive ravalée du ressac" (lbid). Hence, if Marcel Mauss is correct when he argues that magic has little poetry because the demons and the gods involved in magic are like soldiers lacking any real individuality (105), we will venture to say that on the other hand poetry has much magic: the spell of sentiments and resentments of animal words.

Accordingly, the magic music and poetry make is African in nature, at least in the Caribbean world. But what is magic? There is a tendency to equate magic with the primitive and to absolutely distinguish it from religion, as if weighing magic against religion were a heresy of sorts. In an attempt to provide a definition of magic, Mauss does remind his readers that a religion designates the remnants of former cults as magical even when the ceremonies are still being performed in a religious manner (22). In this case, magic is indeed the most childish of skills and possibly also the oldest (Ibid 175). But whether or not magic is childish is up for debate, what matters here is the word skill, magic being a skill, and the fact that instead of providing a definition of magic itself, Mauss ends up defining the magical rite: "any rite which does not play a part in organized cults - it is private, secret, mysterious and approaches the limits of a prohibited rite" (30). It could very well be that magic is in fact the magical rite. But in spite of its private and secretive nature, Mauss insists that magic is a social phenomenon (174), and also borrows Grimm's definition of magic as "a kind of religion, used in the lower spheres of domestic life" (28).

Malinowski-who considers the most important element in magic to be the spell because the spell is that part of magic which is occult and requires knowledge-associates three elements with the belief in magical efficiency: the phonetic effects or imitations of natural sounds, the use of words which invoke, state, or command, and the mythological allusions and references to the culture and traditions of the practitioners (73-74). Not only can these three elements be found in Guillén's "Arte Poética," but they can equally be associated with music and poetry: the sound, the sound the word makes, and the cultural tradition which in Guillén's case is Cuba's past-a slaveholding nation-and the music, magic, and medicine that came with the enslaved.

Although magic is a practice, a skill, and a storehouse of knowledge (its concern with understanding nature and the fact that its most important element is the spell make it so), although religion is a system of faith and worship, and although science is a discipline (and medicine is one of the branches of this discipline), there exist many points of comparison between 
the three elements of this triptych. Malinowski argues that both magic and religion arise and function in situations of emotional stress such as death, illness, failure, unrequited love and unsatisfied hatred, because they offer a solution or escape by way of empowerment or miracles (87). In this case, it appears that a degree of complexity or simplicity would suffice to set religion apart from magic. Immediately, magic would be declared the simpler of the two, and the more primitive, the more childish, perhaps even a precursor to religion. However, the implication that magic is religion at an embryonic stage would render the relationship between magic and religion one of cause and effect and subsequently there would be no religion without magic, its most primitive ancestor. We could even take this a step further and argue that magic is a precursor of medicine and at the same time elucidate the fact that when Mauss and Malinowski are delving into a theory of magic or attempting to define magic, they are not only referring to African magic, but to a universal idea of magic. Furthermore, James Frazer dedicates very few pages to African magic in his monumental work The Golden Bough which is often considered to be one of the most influential books on magic of the $20^{\text {th }}$ century. The Golden Bough, in fact, refers to a painting by Turner, and thus focuses in European rather than African magic. Hence, Africa does not have the monopoly of magic, but magic and Africa will remain nonetheless inseparable.

Which leads to a judgmental problem regarding the identification of some so-called primitive religions, and also a problem of nomenclature: should the reference be to African religions, to African magic, or to African medicine? Are these terms interchangeable? One argument for the designation of African magic has to do with the supposed absence of an established organization and of an ecclesiastical hierarchy in practices such as voodoo, santería, and candomblé. But it could very be that there is in fact an established ecclesiastical hierarchy and an organization, but that it differs from that of the accepted civilized religions. In fact, there is an organization and an established clergy in the religions that have been labeled as magical or animist. Another argument has to do with the exclusionary and secretive nature of magic and the insinuation that if there are secrets it is because there are lies. Established religion is then put as an example: it is open to all. But there are secrets to the religions that have been dubbed civilized, as well as rites of exclusion, forbidden words such as the tetragrammaton, and first truths that the faithful should not try to understand such as the virgin birth and the trinity. Obviously, there exists a secretive nature to the spells cast, but spells do not differ much from miracles, except that miracles are more widely accepted and civilized. In other words, in the civilized worlds it is acceptable to believe in miracles, but believing in magic 
is downright childish. Miracle, the word, miracle, the thought, the story behind it, the act, all in all appears to be more appropriate and truer than sleight of hand or illusionism, but perhaps turning water into wine is nothing but alchemy, or sleight of hand.

Now to science, because as its etymon implies science is knowledge, and therefore, as Mauss suggests, the sciences and medicine in particular were entirely "swamped by magic" because they depended on magic and religion to such an extent that they seem to have grown from them (24): knowledge of herbs, of cures, of poisons, of how to cast spells, to perform miracles, to proselytize, to conduct mass, bury the dead, communicate with the dead, pray, knowledge of the rite, how to organize the rite, and simply knowledge of how to conduct oneself in any given congregation. Science was also, and remains a way of storing acquiring knowledge and of explaining the natural world and natural phenomena: How is one born? How does one die? What is the nature of illness? These questions have all been the focus of magic and religion as well: knowing and explaining, even if it means going against nature in order to attain this goal. Malinowski writes that magic is akin to science in that it always has a definite aim intimately associated with human instincts, needs and pursuits (86). The difference lies in the differentiation between the sacred and the profane. However, if magic becomes a pseudo-science, then it approaches the profane. On the other hand, if science is reified, which it is, then is approaches the domain of the sacred: belief in science, in nothing but science.

Mauss establishes a definite link between magic and not only science but technology as well, precisely because of the importance magic attaches to knowledge and also its concern with understanding nature. "It quickly set up a kind of index of plants, metals, phenomena, beings and life in general, and became an early store of information for the astronomical, physical, and natural sciences. It is a fact that certain branches of magic, such as astrology and alchemy, were called applied physics in Greece. That is why magicians received the name of phusikoi and that the word phusikos was synonym for magic" (177). Here lies the historical reason why medical doctors are called physicians.

\section{BiBLIOGRAPHY}

AGUIRRE, M. (1980): "El Cincuentenario de Motivos de Son." In Guillén, Nicolas. Motivos de Son. La Habana, Editorial Letras Cubanas.

ARNOLD, J. (1990): "Introduction." In Césaire, Aimé. Lyric and Dramatic Poetry, 1946-1982. Charlottesville: The University Press of Virginia. Pp. $\mathrm{XI-XLI.}$ 
AUGIER, A. (1971): Nicolás Guillén. Havana: Contemporaneos.

BAJEUX, J-C. (1983): Antilia retrouvée. Quebec: Editions Caribéennes.

BAKHTIN, M. (1981): The Dialogic Imagination. Austin: University of Texas Press.

CARPENTIER, A. (2001): Music in Cuba. Minneapolis: University of Minnesota Press.

CASTERA, G, ed. (2003): Anthologie de la littérature haïtienne: Un siècle de poésie, 1901-2001. Montréal: Mémoire d'encrier.

CÉSAIRE, A. (1990): Lyric and Dramatic Poetry, 1946-1982. Charlottesville: The University Press of Virginia.

(1983) : Cahier d'un retour au pays natal. Paris and Dakar: Présence Africaine.

COBB, M. 91979): Harlem, Haiti, and Havana. Washington, D.C.: Three Continents Press.

FEIJOO, S. (1986): El son cubano: poesía general. Havana: Letras Cubanas. COUFFON, C. (1964): Nicolás Guillén. Paris: Seghers.

ELLIS, K. (1983): Cuba's Nicolás Guillén: Poetry and Ideology. Toronto: University of Toronto Press.

FRAZER, J. (1950): The Golden Bough. New York: Macmillan.

GONZÁLEZ ECHEVARRÍA, R. (1993): Celestina's Brood. Continuities of the Baroque in Spanish and Latin American Literature. Durham: Duke University Press.

GUILLÉN, N. (1977): Summa Poetica. Luis Iñigo Madrigal, ed. Madrid: Cátedra.

(1980): Motivos de Son. La Habana, Editorial Letras Cubanas.

(1948): Cuba Libre. Poems by Nicolás Guillén. Trans. Langston Hughes and Ben Frederic Carruthers. Los Angeles: The Ward Ritchie Press.

HENNESSY, A. (2005): "Introduction." Nicolás Guillén: Yoruba from Cuba. Leeds: Peepal Tree Press.

KLEIN, E. (1971): Klein's Comprehensive Etymological Dictionary of the English Language. Amsterdam: Elsevier.

KRISTEVA, J. (1983): Histoires d'amour. Paris: Editions Denoël.

KUBAYANDA, J. (1990): The Poet's Africa. Africanness in the Poetry of Nicolás Guillén and Aimé Césaire. New York: Greenwood Press.

KUTZINSKI, V. (1987): Against the American Grain. Baltimore: The Johns Hopkins University Press.

LÓPEZ-BARALT, M. (2009): Orfeo Mulato. San Juan: Editorial Universidad 
Puerto Rico.

MAGLIA, G. (2009): De la machina imperial a la vereda tropical: Poesía, identidad y nación en el Caribe afrohispánico. Bogotá: Editorial Pontificia Universidad Javeriana.

MALINOWSKI, B. (1992): Magic, Science and Religion. Prospect Heights, Illinois: Waveland Press.

MARTÍ, J. (1982): Major Poems. Bilingual Edition. Philip S. Foner, ed. New York and London: Holmes \& Meier.

MARtíNEZ ESTRADA, E. (1972): La Poesía de Nicolás Guillén. Buenos Aires: Calicanto, 1977.

MAUSS, Marcel. A General Theory of Magic. London and New York: Routledge.

PAZ, O. (1996): El arco y la lira. México: Fondo de Culture Económica.

SARTRE, J-P. (1948) : "Orphée Noir." In, Anthologie de la nouvelle poésie nègre et malgach.

SENGHOR, L., ed. Paris: Presses Universitaires de France.

SENGHOR, L. (1948): Anthologie de la nouvelle poésie nègre et malgache. Paris: Presses Universitaires de France.

SMART, I. (1990): Nicolás Guillén: Popular Poet of the Caribbean. Columbia: University of Missouri Press.

PALÉS MATOS, L. (1993): Tuntún de pasa y grifería. San Juan: Editorial de la Universidad de Puerto Rico.

SAINT-LOUIS, C., and M. LUBIN. (1950) : Panorama de la poésie haïtienne. Port-au-Prince: Editions Henri Deschamps.

WHITE, C. (1993): Decoding the Word: Nicolás Guillén as Maker and Debunker of Myth.

MIAMI, Fla.: Ediciones Universal.

WILSON, L. (1979): La poesía afroantillana. Miami, Fla.: Ediciones Universal. 